\title{
ステップ状応力変化に対する超音波 伝ぱ速度の応答についで
}

\author{
金 持 昭 治** 赤星通次郎** 水 野 兼 雄 ${ }^{* *}$
}

\section{On the Response of Ultrasonic Velocity to Stepwise Change of Stress Condition}

by

\author{
Shoji Kanemochi, Michijiro Akaboshi and Kaneo Mizuno \\ (Faculty of Engineering, Osaka Electro-Communication University, Neyagawa)
}

In an experimental study of acousto-elastic effect, some anomalous phenomena in ultrasonic velocity, that could not be interpreted by the lattice anharmonicity, have been observed. In this paper, we have observed in detail the behaviors of an ultrasonic velocity propagating in a copper specimen (99.98\% of purity) perpendicularly to the stress axis, as the uniaxial tensile and compressive stresses exceeding the range of plastic deformation were applied or released stepwisely. The results obtained are summarized as follows:

(1) The decrease of the traveling time (in a traveling path of $10 \mathrm{~mm}$ ) after one minute of stress application under a constant stress level $\left(\Delta T_{m}\right)$ seems to be related with the pinning of dislocation lines similar to the Köster effect.

(2) The difference between the traveling time at To and that after stress release $\left(\Delta T_{o r}\right)$ increased with the plastic strain $\left(\varepsilon_{\mathrm{ply}}\right)$. The dislocation is in un-stable state when the plastic strain appears, so that its mobility becomes larger. Even in the elastic range, $\Delta T_{\text {or }}$ was observed.

(3) The change in traveling time $\left(\Delta T_{a}\right)$ during stress application increased parabolically with the stress in the elastic range, similar to $\left(\Delta T_{r}\right)$ during stress release. When some plastic strain pre-existed, they decreased at first depending on the amount of the plastic strain, reached a minimum, and then increased with the stress.

キー・ワード：超音波伝ぱ速度, 応力低存性, ステップ応答

(Received May 19, 1978)

\section{1 緒言}

鋼, 銅拉よびアルミニウムなどの金属材料に打沙る

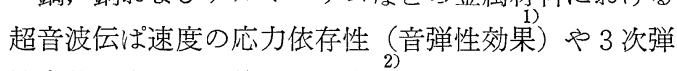
性定数の実測を目的とした実験の際に，筆者らは，一 定応力状態や除荷後の無応力状態において, 伝ぱ速度 が徐々飞增加すること, 除荷後の伝ぱ速度は応力の履 歴に上る影響が大きいこと，塑性ひずみが生じた場合 の伝ぱ速度は複雑な挙動を示すことなどを経験的に知 った．当初，これらの現象は実験方法にも一因がある ものと思われたが，容駼を重㸚るに従い，末た低応力 においても転位の影響が考光られることから，これら の現象も同様に，転位の影響として説明できるものと 思われる.

そこで, 本研究では, 銅多結晶金属について, 単軸 引張りおよび圧縮応力をステップ状に負荷就よび除荷

* 原稿受理 昭和53年 5 月19日

** 正会 員 大阪電気通信大学 隻屋川市初町
したときの超音波 $(5 \mathrm{MHz})$ 伝ぱ速度の応答を詳細に 測定し検討した.な秥, 応力範囲は塑性域まで含み, 超望波の伝ぱ方向は応力軸に垂直であり，また応力軸 に垂直に偏向した横波を用いた.

\section{2 実験装置および試料}

一定応力状態に比較的長く（20分間）保ち，その之 きの超音波伝ぱ速度の挙動を測定するため, 応力（単 軸応力）の負荷は引張り，圧縮とも Fig. 1 飞示す重 すいとレバーからなる装置で行った. Fig.1 は引張り の場合を示し，圧縮の場合はレバーを左右逆にして取 り付ける。 また, 応力値 $\left(\sigma_{y}\right)$ の算出は, 重すいとレ バー比で定る軸荷重を試片断面積 $\left(1.89 \mathrm{~cm}^{2}\right)$ で割っ て求めた。低応力範囲（約 $50 \mathrm{~kg} / \mathrm{cm}^{2}$ 以下）に括いて はひずみ計式ロードセルを併用し，これらの間に差違 のないことを確めた.

試片の表裏に貼り付けたひずみゲージにより，それ らの平均として応力方向のひずみ（敫）を測定した. 


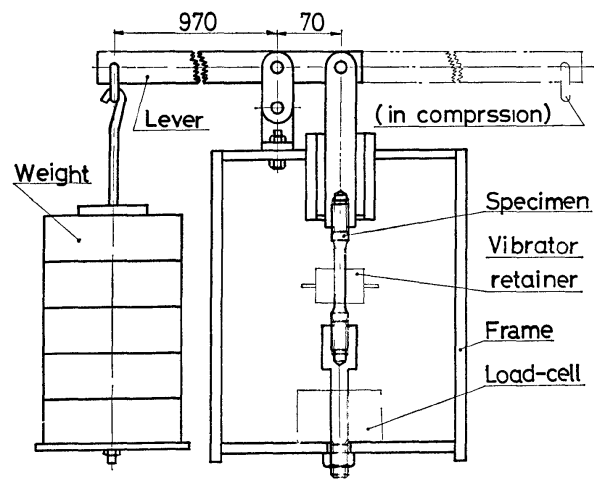

Fig. 1. The equipment of stress application in an arrangement for tensile stress. The lever would be re-arranged for compressive stress, as shown in the figure. A load-cell was used in the stress level lower than $50 \mathrm{~kg} / \mathrm{cm}^{2}$. The vibrator retainer has been shown in Ref. 2).

超音波伝ぱ速度，実際には無応力状態での伝ぱ距離 $\left(L_{0}\right)$ が $10 \mathrm{~mm}$ である試片を通過する時間 $(T)$ の測 定はシングアランド (sing-around) 装置で行い, ペ ンレコーダに記録した．送受信振動子（直径 $10 \mathrm{~mm}$, 共振周波数 $5 \mathrm{MHz}$ ) の試片への取付は特殊な金具を 用いて行った. シングアランド装置は $+0.015 \mu \mathrm{s} /{ }^{\circ} \mathrm{C}$ の温度特性があるため, 環境温度の変化を極力避けた。 また，測定した伝ぱ時間 $(T)$ をすべて， $25^{\circ} \mathrm{C}$ の值に補 正した.

試料は市販銅丸棒 $(99.98 \%)$ を所要の形状に加工し $4500^{\circ} \mathrm{C} 8 \mathrm{~h}$ の焼なましを行って実験に供した。なお引 張りと圧縮では別の試片を用いた。

\section{3 実 験 方 法}

既に述べたよらに，超音波伝ぱ時間 $(T)$ は一定応力 状態においても徐々に減少することなどが知られてい たため, 本研究では, ある応力 $\left(\sigma_{y}\right)$ をステップ状に負 荷し，そのまま20分間保持した後，ステップ状に除荷 した。ささらに 20 分経過したとき，より大きな応力を 負荷し，以後この上うな応力サイクルを繰返した.

(Fig. 2 参照). 数回の応力サイクルを一実験グループ とし, 同じ応力範囲である実験グループを 2 回ずつ行 った (Table I 参照).

Fig. 2 は，上記のように応力を負荷したときの伝ぱ

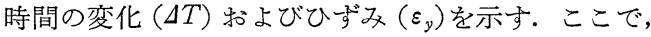
$T_{0}$ は実験開始前の伝ぱ時間， $\Delta T_{a}$ は負荷時に応答す る伝ぱ時間の変化， $\Delta T_{r}$ は除荷時に応答する伝ぱ時間 の変化, $\Delta T_{m}$ は負荷後 1 分間の伝ぱ時間の減少（減 少速度）および $\Delta T_{\text {or }}$ は除荷時（無応力状態）の伝ぱ 時間と $T_{0}$ との差を示す．また， $t_{c}$ は実験グループ間の 時間（試料の放置時間）であり，30分未満を切り捨て て, Table I に示す. さらに， $\varepsilon_{\text {ply }}$ は塑性ひずみ, $\Delta \varepsilon_{\mathrm{ply}}$ は実験グループ内で生じた塑性ひずみを示す.
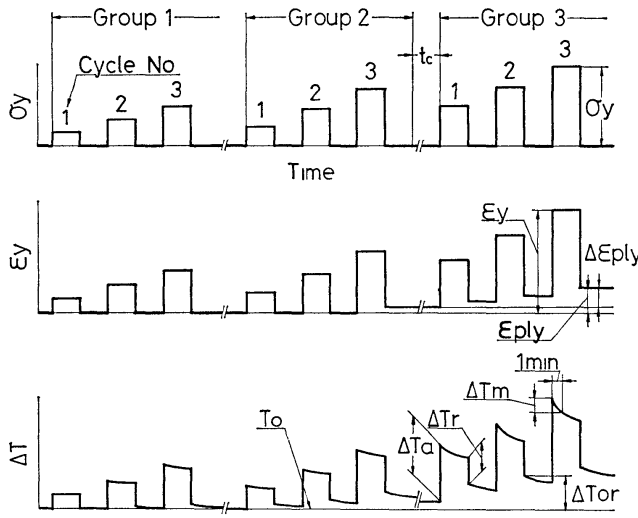

Fig. 2. Cycles of stress applied $\left(\sigma_{y}\right)$, strain $\left(\varepsilon_{y}\right)$ and change of the traveling time $(\Delta T) . \varepsilon_{\mathrm{ply}}$; plastic strain in the stress direction. $\Delta \varepsilon_{\text {ply }}$; plastic strain introduced in the experimental group. $T_{0}$; traveling time at the beginning of this work. $\Delta T_{a}$; change of the traveling time when a stress was applied. $\Delta T_{r}$; change of the traveling time when a stress was released. $\Delta T_{m}$; decrease of the traveling time in one minute after a stress application. $\Delta T_{o r}$; difference of the traveling time between $T_{0}$ and that when a stress was just released.

Table I. Experimental group and its stress level $\left(\sigma_{y}\right)$, symbol plotted in Figs., plastic strain introduced in the group $\left(\Delta \varepsilon_{\text {ply }}\right)$ and time interval between each group $\left(t_{c}\right)$.

\begin{tabular}{|c|c|c|c|c|c|c|c|}
\hline \multirow{2}{*}{$\sum_{0}^{0}$} & \multirow{2}{*}{\begin{tabular}{|l|}
$\hat{\sigma}$ \\
$\hat{\xi}$ \\
nै
\end{tabular}} & \multicolumn{2}{|c|}{$\sigma y\left(\mathrm{Kg} / \mathrm{cm}^{2}\right)$} & \multicolumn{2}{|c|}{$\Delta$ Eply $\left(10^{-6}\right)$} & \multicolumn{2}{|c|}{ tc $(h)$} \\
\hline & & Ten. & Comp. & Ten & Comp & & \\
\hline 1 & 0 & $18 \sim 87$ & $19 \sim 90$ & 3 & 4 & & \\
\hline 2 & $\bullet$ & $18 \sim 87$ & $19 \sim 90$ & 2 & 1 & 0 & 1 \\
\hline 3 & 0 & $61 \sim 118$ & $51 \sim 106$ & 7 & 5 & 0 & 2 \\
\hline 4 & - & $61 \sim 118$ & $51 \sim 106$ & 4 & 0 & 0 & 13 \\
\hline 5 & (1) & $92 \sim 145$ & $114 \sim 174$ & 16 & 37 & 32 & 0 \\
\hline 6 & $\theta$ & $92 \sim 145$ & $114 \sim$ & 28 & & 17 & 16 \\
\hline 7 & 0 & $124 \sim 229$ & $140 \sim 243$ & 125 & $\frac{1}{192}$ & 0 & 4 \\
\hline 8 & $\theta$ & $124 \sim 229$ & $140 \sim 243$ & 18 & 30 & 0 & 1 \\
\hline 9 & $\oplus$ & $176 \sim 303$ & $203 \sim 293$ & 390 & 425 & 0 & 0 \\
\hline 10 & $\odot$ & $176 \sim 303$ & $203 \sim 293$ & 30 & 63 & 0 & 0 \\
\hline
\end{tabular}

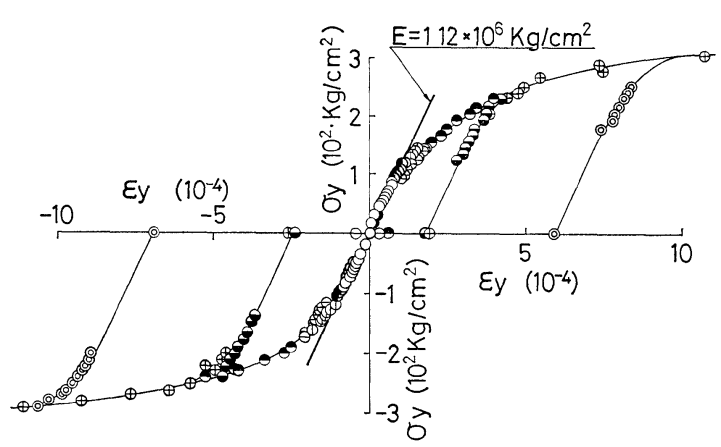

Fig. 3. Stress-strain diagram. E; Young's modulus. 
Table I は実験グループの応力範囲, $\Delta \varepsilon_{\text {ply }}$, 拉よび $t_{c}$ を示す. また，記号 (Symb.) は以下の図に用いるも のである.

Fig. 3 は応力を負荷したときの $\sigma_{y}$ と $\varepsilon_{y}$ を用いて 得られた応力ーひずみ線図である。十ング率 $(E)$ は $1.12 \times 10^{6} \mathrm{~kg} / \mathrm{cm}^{2}$ となった.

\section{4 実験結果および㭘討}

\section{$4 \cdot 1$ 定応力状態での伝ぱ時間の変化（減少）}

応力を負荷した後の一定応力状態に抢祃超音波伝 ぱ時間の減少について, 負荷後 1 分間の伝ぱ時間の減 少量（減少速度） $\left(\Delta T_{m}\right)$ を Fig. 4 亿示す. 同様な現 象は除荷時にもみられたが，定性的な差違はなく省略 する。

Fig. 4 飞拈いて, $\Delta T_{m}$ は引張り, 圧縮とも応力の 増加につれてほぼ放物線状に増加しているが，大きな 塑性ひずみが生じた実験グループ(G. No.7, Table I 参照) 以降 $\left(\sigma_{y}\right.$ が約 $\pm 1.7 \times 10^{2} \mathrm{~kg} / \mathrm{cm}^{2}$ 以上) 飞抒 いては, 応力の増加につれて $\Delta T_{m}$ は減少し, ばらつ きも大きくなっている.

一定応力状態で, ひずみの增加（クリープ）るなく 伝ぱ時間が減少することは, (2 次)弾性率が大きくな っていると考兄られる.

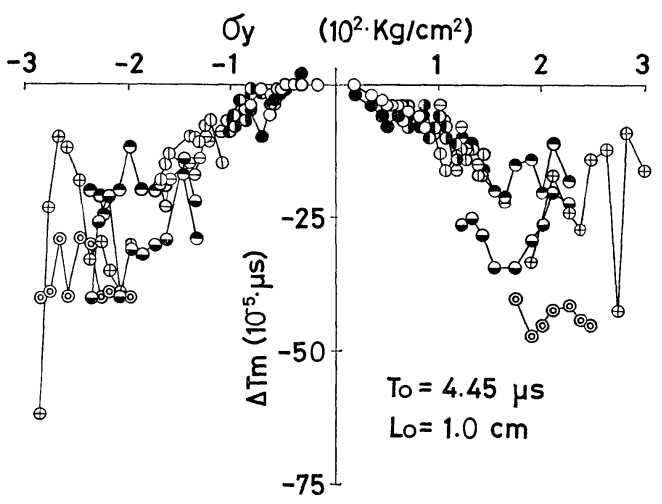

Fig. 4. Decrease of the traveling time in one minute after a stress application $\left(\Delta T_{m}\right.$, rate of the decrease) against the stress $\left(\sigma_{y}\right)$.

超音波の伝ぱ速度や内部摩擦と転位との関係は転位 線の絃モデルで説明されることが一般である。そこで, 弾性率の増大は転位線の平均固着点長さの減少汶対応 $l_{4}$, この現象 $\left(\Delta T_{m}\right)$ も, 内部摩擦に拈ける Köster 効 果と同じく, 応力の負荷により固着点から離脱した転 位線が再びくぎづけされることであると考光られる。 な特, 転位線の固着点からの離脱は, 低応力 $(0.1 \mathrm{~kg} /$ $\mathrm{cm}^{2}$ 以下) に拈いても生ずることが示されている.

\section{$4 \cdot 2$ 除荷直後の伝ぱ時間}

実験開始前の伝ぱ時間 $\left(T_{0}\right)$ に対する, 応力を除荷 したとき（無応力）の伝ぱ時間の差（ $\left(\Delta T_{o r}\right)$ を Fig.

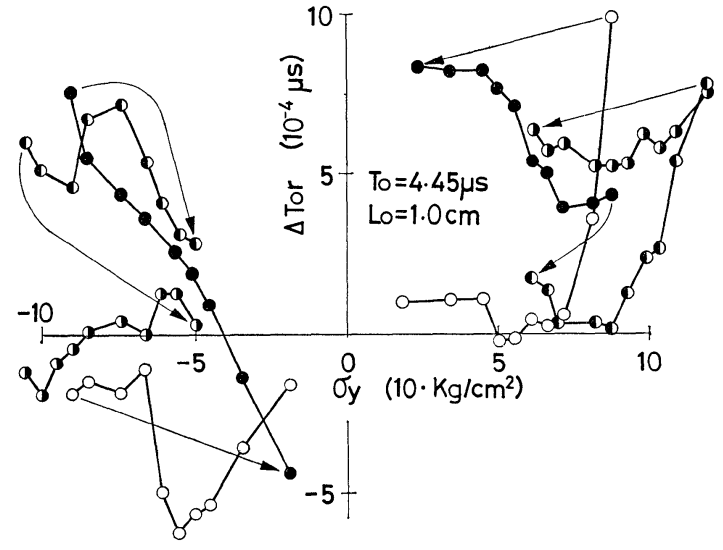

Fig. 5. Difference of the traveling time between $T_{0}$ and that when a stress was just released $\left(\Delta T_{o r}\right)$ against the stress $\left(\sigma_{y}\right)$ in low stress level.

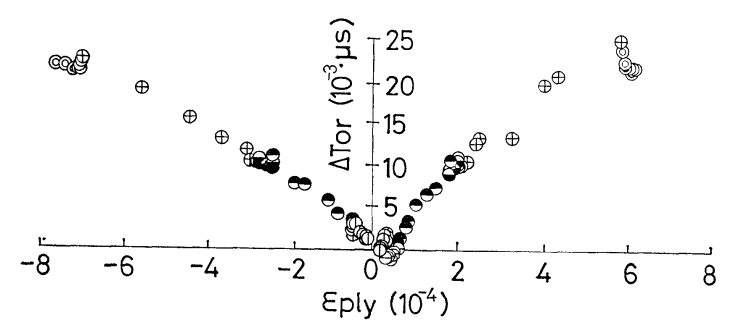

Fig. 6. Difference of the traveling time between $T_{0}$ and that when a stress was just released $\left(\Delta T_{o r}\right)$ against the plastic strain $\left(\varepsilon_{\mathrm{ply}}\right)$.

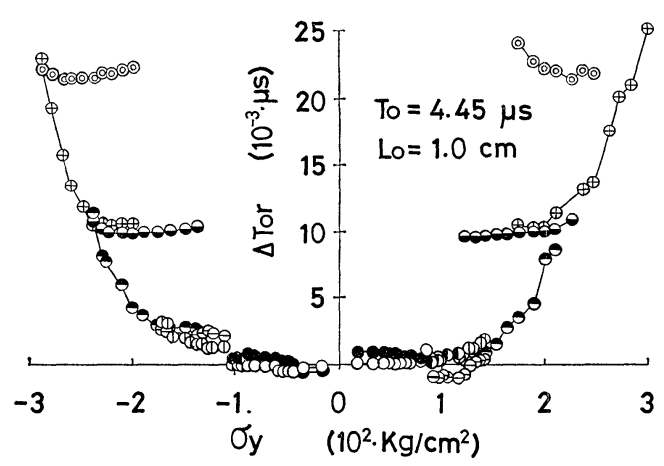

Fig. 7. Difference of the traveling time between $T_{0}$ and that when a stress was just released $\left(\Delta T_{o r}\right)$ against the stress $\left(\sigma_{y}\right)$ in higher level.

5〜7 に示す.

Fig. 5 は低応力範囲（実験グループの 4 以下）の $\Delta T_{\text {or }}$ を㐫力 $\left(\sigma_{y}\right)$ 飞対して示したものである. まず, 引張り側に扔いて，実験グループ番号(G. No.) 1 の が $65 \mathrm{~kg} / \mathrm{cm}^{2}$ 以上で $\Delta T_{\text {or }}$ は急激飞增加している. し かし，G.No.2では応力の増加につれて $\Delta T_{\text {or }}$ は減少 している. G. No.1, 2 での $\Delta \varepsilon_{\mathrm{ply}}$ は乞れぞれ $4,1 \times$ $10^{-6}$ と小さく, 測定精度に比較して有意性は小さいが, 
$\Delta T_{\text {or }}$ が急激に増加したととは，微視的な塑性ひずみ が生じ，転位線の離脱した状態に対応すると思われ， 同じ応力範团である G. No. 2 では， G. No.1 で離脱 した転位線が再びくぎづけされることに対応するもの と思われる. また，G.No. 3 と G. No. 4 でも同様の 傾向が反られる. しかし, 圧縮側の G. No.1 では, $\Delta T_{\text {or }}$ は初めに減少し, その後増加していることや, G. No. 2 では $\sigma_{y}$ に皃ぼ比例したような増加をしてい ることなど, 引張側と一致しない，ただし，G. No.3 と G. No. 4 は引張側と類似した傾向である.これは, 応力の負荷または除荷により, 転位線の離脱と固着の どちらが優位になるかは, 材料の状態に微妙に影響さ れるものと思われる.

Fig. 3 で示されたように, G. No. 4 以下は一般には 弾性域として扱われる範囲であるが，応力の負荷によ り $\Delta T_{\text {or }}$ は $2 \times 10^{-3} \mu \mathrm{s}, \Delta T_{\text {or }} / T_{0}$ にして $4.5 \times 10^{-4}$ 程 度の範囲内を上下寸るものと考光られる。これは, 弾 性率変化 $\left(\Delta M / M_{0}\right)$ 飞して約 $10^{-3}$ となり，4桁以上 の精度で弾性率を測定することが困難であることの一 因であうら.

Fig. 6 はより大きな範囲での $\Delta T_{\text {or }}$ を $\varepsilon_{\mathrm{ply}}$ に対し て示したものであり, Fig. 7 は $\sigma_{y}$ に対して示したも のである. Fig. 6 亿示すように, 塑性ひずみが生じた ときの $\Delta T_{o r}$ は $\varepsilon_{\mathrm{ply}}$ に対して単調に増加している.こ れはまた， $\sigma_{y}$ に対して示した Fig.7 に执いて， $\Delta T_{\text {or }}$ は Fig. 3 に和ける $\varepsilon_{y}$ と似た変化を示していることに も示されている.

塑性ひずみが生じた場合, 伝ば距離 $(L)$ も当然变化 して叔り，その影響が考光られるが，Fig.6 に秃いて 引張り, 圧縮ともに, $\varepsilon_{\mathrm{ply}}$ に対する $\Delta T_{\text {or }}$ は対称的に 增加していることから，Lの変化による影響は小さく， 無視できるものと考党られる.

以上のように, 塑性ひずみが生じ, 転位密度が増加 すると $\Delta T_{\text {or }}$ が增加, すなわち, 弾性率が低下するこ とは, 絃モデルの結果と定性的に一致している.な拉, $\Delta T_{\text {or }}$ は除荷直後の值であり, 前節 $(4 \cdot 1)$ で述べたご 之き現象により, 增殖した転位線が徐々に固着され, 弾性率も㐫る程度回復すると考光られる。

\section{$4 \cdot 3$ 負荷および除荷に応答する伝ぱ時間の変化}

応力を負荷したとき沁答する伝ぱ時間変化 $\left(\Delta T_{a}\right)$ および除荷したときに応答する伝ぱ時間変化 $\left(\Delta T_{r}\right)$ を それぞれ，Fig. 8 特よび Fig. 9 亿示す. ただし， $\Delta T_{r}$ の符号は, 除荷の際に伝ぱ時間が短かくなる場合を正 とした．したがって， $\Delta T_{a}$ が正で $\Delta T_{r}$ が負である場合 の伝ぱ時間の応答は, Fig. 10 (引張側の G. No.8, 応 カサイクル2番目）飞示すよう以, 負荷時も除荷時も 伝ぱ時間は増加していることになる。

Fig. 8, 9 亿示すように, $\Delta T_{a}$ と $\Delta T_{r}$ は非常によ

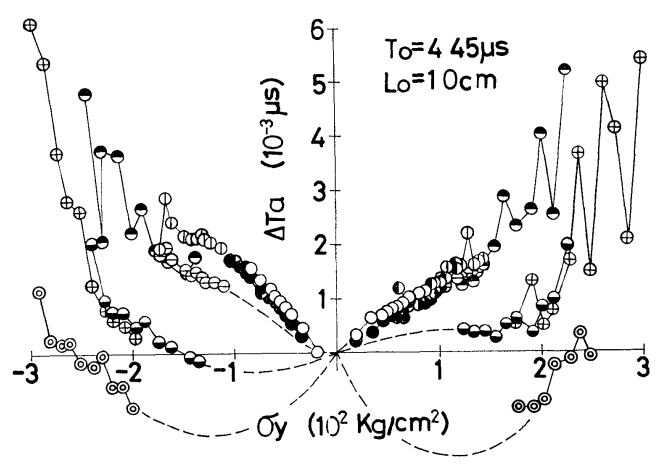

Fig. 8. Change of the traveling time when a stress was applied $\left(\Delta T_{a}\right)$ against the stress $\left(\sigma_{y}\right)$.

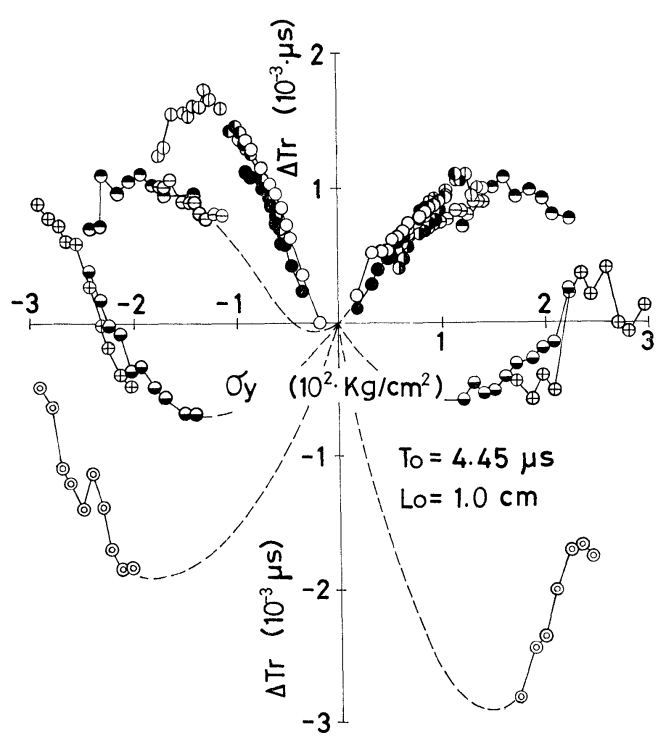

Fig. 9. Change of the traveling time when a stress was released $\left(\Delta T_{r}\right)$ against the stress $\left(\sigma_{y}\right)$.

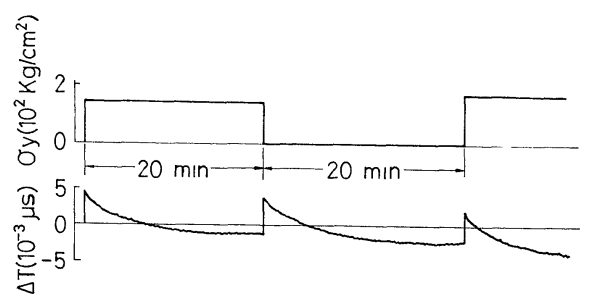

F1g. 10. A typical response of the traveling time which increased with the stress at appling and at releasing.

く似た傾向を示している。まず， $\pm 100 \mathrm{~kg} / \mathrm{cm}^{2}$ 以下 の低応力では, $\Delta T_{a}, \Delta T_{r}$ とも $\sigma_{y}$ に対してほぼ放物 線状に増加している.ささらに $\sigma_{y}$ が増加し塑性ひずみ が生じ始めると $\Delta T_{a}$ の増加率は減少し, $\Delta T_{r}$ は（そ れ自身) 滅少している. 塑性ひずみは負荷時住じ, 除荷時には生じないことや，塑性ひずみが生じたとき の $\Delta T_{\text {or }}(4 \cdot 2$ 節参照) はかなり大きくなっているこ となどから， $\Delta T_{a}$ と $\Delta T_{r}$ に差違が生じるものと思わ 
れる。

また，塑性ひずみが生じた場合，次の実験グループ の $\Delta T_{a}, \Delta T_{r}$ はそれまでの結果から推定される值より 小さく, 別の曲線で示されるよらな変化を示している. さらに, その低応力範囲は Fig. 8, 9 の破線で示され

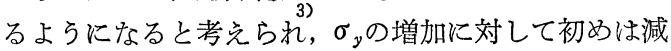
少し極小值を経て増加すると思われる. 大きな塑性ひ ずみが生じた後の材料の転位組織は不安定で, その易 動度も大きい状態にあると思われる. したがって，そ のような状態で応力を負荷したとき，転位線の固着は 離脱よりも多く生じ, $\Delta T_{a}, \Delta T_{r}$ が低応力で減少する ものと考光られる.ささに応力が増加すれば，離脱の ほらが優位になるものと考光られ，低応力に打る $\Delta T_{\text {or }}$ の挙動と類似している.

Fig. 11 は $\left(\Delta T_{a}-\Delta T_{r}\right)$ と $\sigma_{y}$ との関係を示したも ので，注㳊物線状を示している，低応力に和壮る $\left(\Delta T_{a}-\Delta T_{r}\right)$ はそのような応力でも微視的な塑性ひず みが生じていると考えるか，一定応力状態や無応力状 態での保持時間を長くし, 転位組織が完全に安定（固 着）するようにすれば消隇すると考えることができる。

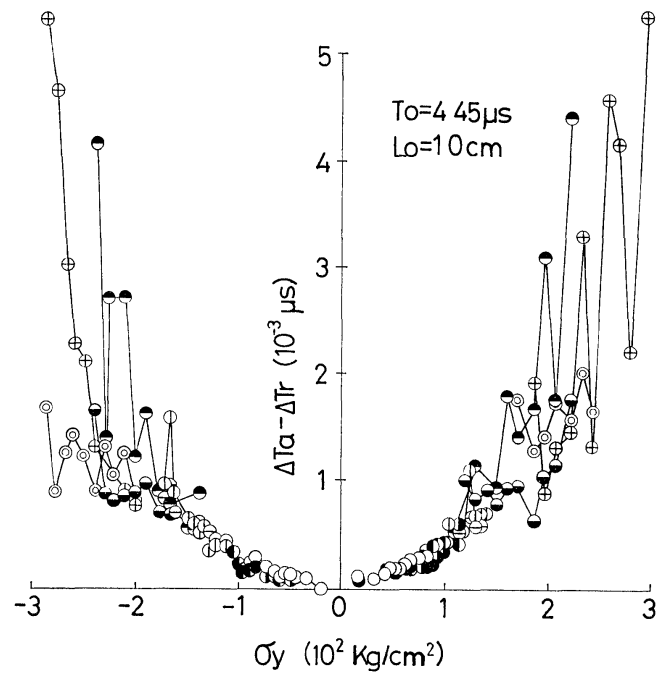

Fig. 11. Difference of the traveling time changes $\left(\Delta T_{a}-\Delta T_{r}\right)$ against the stress $\left(\sigma_{y}\right)$.

なお，転位組織の超音波伝ぱ速度への影響は，転位 線の絃モデルを用いて考察することが普通であるが， 転位線張力がわん曲により変化するといら非線形な絃
モデル゙ルより，転位線の離脱や固着によらない説明も 可能である. しかし，今のところどちらがより自然で あるかは不明である。

$$
5 \text { 結言 }
$$

単軸応力をステップ状に負荷および除荷したとさの 銅試料 (99.98\%) についての超音波伝ぱ時間（伝ぱ距 離は $10 \mathrm{~mm}$ ) の応答を測定し検討した.ただし，使用 した超音波の共振周波数は $5 \mathrm{MHz}$ であり，応力方向 と垂直に偏向した横波である.

結果を要約し以下に示す.

（1）一定応力状態や除荷後の無負荷状態に扣いて， 超音波伝ぱ速度は徐々に増加したが(伝ぱ時間は減少), これは Köster 効果と同様に, 転位の固着に関係して いると思われる。

（2）除荷直後の伝ぱ時間の実験前の伝ぱ時間に対す る差 $\left(\Delta T_{o r}\right)$ は, 大略的には塑性ひずみに対応して増 加した. これは, 応力の正負（引張り, 圧縮）にかか わらず同じ傾向であり，伝ぱ距離の変化とは関連しな い. 伝ぱ時間の増加は, 弾性率の低下を意味し, 除荷 直後の転位組織は不安定でその易動度が大きい状態で あると考劣られる。な拉, 弾性域と思われる低応力に おいても，わずかな $\Delta T_{\text {or }}$ は観察された。

（3）負荷および除荷に応答する伝ぱ時間の変化 $\Delta T_{a}$ および $\Delta T_{r}$ は，よく似た傾向を示し，弾性域ではほ ぼ放物線状に増加した．塑性ひずみが生じた場合の次 の実験での $\Delta T_{a}, \Delta T_{r}$ は， $\sigma_{y}$ の増加に対してはじめ は減少し極小值を経て増加した. これは，上述のよう に，塑性ひずタが生じた場合の転位組織が不安定であ ることに関連していると思われる。

\section{参 考 文 献}

1）金持昭治, 水野兼雄, 赤星通次郎, 材料, 26, 289(1977).

2）金持昭治, 赤星通次郎, 水野兼雄, 材料, 27, 974(1978).

3) Rosenfield, A. R., G. T. Hahn, A. H. Bement, Jr., and R. I. Jaffee, "Dislocation Dynamics", McGraw-Hill (1967).

4）日本金属学会編，“転位論”（1971）丸善

5）実吉純一，菊地喜充，能本乙彦，“超音波技術便覧”, (1966) 日刊工業新聞

6) Granato, A. V., and K. Lücke, J. A. P., 27, 583 (1956).

7) Hikata, A., and C. Elbaum, Phys. Rev., 144, 469 (1966). 